\title{
ANALISIS PROSES BERPIKIR ANAK BERKEBUTUHAN KHUSUS (ABK) DALAM MENYELESAIKAN MASALAH MATEMATIKA DI SMP INKLUSI KOTA METRO \\ (Studi Kasus pada Siswa Tunagrahita Ringan)
}

\author{
Nurain Suryadinata $^{1)}$, Nurul Farida ${ }^{2)}$ \\ Pendidikan Matematika FKIP Universitas Muhammadiyah Metro \\ Email: ${ }^{1)}$ math@nsdinata15.com \\ ${ }^{2)}$ nurulfarida.maniz@yahoo.com
}

\begin{abstract}
The aims of the research is to describe the thinking process at mild intellectual disability students to solve mathematics problem. The research was a descriptive qualitative. The subjects of the research was students of grade eight SMPN 5 Metro. Technique analyzing of the data were: (1) classifying the data, (2) presenting the data, and (3) concluding the data in each categories. The results of the research showed that thinking process for mild intellectual disability students : (1) mild intellectual disability students can establishnment understanding in thinking process; (2) mild intellectual disability students can't establishnment opinion and students cant't using the right strategy to solve mathematics problem; (3) mild intellectual disability can't give conclusion.
\end{abstract}

Keywords: mathematics problem, mild intellectual disability, thinking process

\section{PENDAHULUAN}

Setiap warga negara berhak mendapatkan pendidikan yang layak sebagaimana tercantum dalam UUD 1945 Pasal 31 ayat 1 bahwa tiap warga negara berhak mendapat pendidikan, termasuk warga negara yang memiliki kelainan fisik, mental, emosional, intelektual, dan sosial. Hal ini menunjukkan bahwa Anak Berkebutuhan Khusus (ABK) memiliki hak yang sama dengan anak normal pada umumnya. ABK dalam pendidikan inklusi memperoleh pendidikan yang bermutu sesuai dengan kebutuhan dan kemampuannya sebagaimana yang tercantum dalam Permendiknas No 70 tahun 2009 pasal 1 bahwa pendidikan inklusif memberikan kesempatan kepada semua peserta didik yang memiliki kelainan dan bakat yang istimewa untuk mengikuti pendidikan dalam satu lingkungan pendidikan bersama dengan peserta didik pada umumnya. Dengan demikian, anak yang memiliki kebutuhan khusus dapat belajar bersamasama dengan anak yang normal. 
Salah satu upaya pemerintah untuk melakukan pemerataan layanan pendidikan adalah dengan menyelenggarakan pendidikan inklusi. Kota Metro merupakan salah satu kota yang ditunjuk pemerintah untuk menyelenggarakan pendidikan inklusi. Salah satu SMP yang ditunjuk untuk menyelenggarakan pendidikan inklusi adalah SMP N 5 Metro. Berdasarkan observasi awal dengan guru yang ada di SMP N 5 Metro bahwa di sekolah tersebut menerima Anak Berkebutuhan Khusus (ABK) melalui jalur khusus, yakni dengan mendatangkan guru dari sekolah luar biasa untuk menyeleksi ABK. Menurut Geniofam (2010), anak berkebutuhan khusus adalah anak dengan karakteristik khusus yang berbeda pada umumnya tanpa selalu menunjukkan pada ketidakmampuan mental, emosi atau fisik.

Pada sekolah tersebut, proses pembelajaran yang dilakukan oleh guru kelas inklusi, terutama pembelajaran matematika masih menggunakan kurikulum yang sama. Pembelajaran yang dilakukan adalah pembelajaran klasikal. Media yang digunakan juga belum maksimal dengan perbedaan karakteristik peserta didik yang dimilki, terutama untuk ABK.
Di SMP Negeri 5 Metro terdapat ABK dalam kelompok kelainan mental yaitu tunagrahita ringan. Untuk siswa tunagrahita ringan ini, dalam pembelajarannya sangat memerlukan bantuan secara khusus. Menurut Abdullah (2013), pada anak tunagrahita ini untuk meniti tugas perkembangannya memerlukan bantuan atau layanan secara khusus, terutama di dalamnya kebutuhan program pendidikan dan bimbingannya.

Seorang guru hendaknya memiliki kreativitas dalam menyampaikan materi pelajaran terutama pelajaran matematika dengan perbedaan karakteristik yang dimilki peserta didiknya terutama siswa $\mathrm{ABK}$ terlebih lagi bagi siswa tunagrahita ringan.

Seorang guru perlu memiliki informasi mengenai proses berpikir peserta didiknya supaya memiliki gambaran dan dapat memilih serta menentukan metode yang tepat untuk pembelajaran matematika pada kelas inklusi. Menurut Breen dan O'Shea (2010), dalam rangka mengembangkan kemampuan matematika, perlu bagi seseorang untuk tidak hanya menguasai isi dari matematika tersebut, tetapi penting juga untuk mengembangkan keterampilan berpikirnya.

Lebih lanjut Arends (2008) menjelaskan bahwa berpikir adalah kemampuan untuk 
menganalisis, mengkritik dan mencapai kesimpulan berdasarkan inferensi atau judgement yang baik. Lebih lanjut, proses berpikir menurut Suryabrata (2014) terdiri dari tiga langkah pokok yaitu: (1) pembentukan pengertian, (2) pembentukan pendapat, dan (3) penarikan kesimpulan. Dalam matematika, proses berpikir ini dapat dilihat melalui pemberian suatu masalah. Menurut Marchis (2012), saat belajar matematika, siswa menyelesaikan latihan dan masalah sehingga lebih bisa mendapatkan pengetahuan dan mengembangkan keterampilan matematika yang mereka miliki.

Berdasarkan beberapa penjelasan tersebut, informasi awal yang cukup dibutuhkan untuk lebih meningkatkan proses pembelajaran di kelas inklusi adalah mengenai proses berpikir $\mathrm{ABK}$ tunagrahita ringan dalam menyelesaikan masalah matematika. Dengan demikian, diharapkan proses pembelajaran matematika pada kelas inklusi lebih bermakna dan optimal terlebih bagi kelas inklusi yang terdapat siswa tunagrahita ringan di dalamnya.

\section{METODE PENELITIAN}

Penelitian ini merupakan penelitian deskriptif kualitatif yang bertujuan mendeskripsikan proses berpikir siswa tunagrahita ringan dalam menyelesaikan masalah matematika. Penelitian ini dilakukan pada siswa kelas VIII SMP Negeri 5 Metro semester genap Tahun Ajaran 2015/2016. Waktu penelitian berlangsung sejak bulan Januari 2016 sampai Mei 2016 yang dimulai dari tahap persiapan, pengambilan data sampai dengan tahap penyusunan laporan hasil penelitian.

Subjek penelitian ini adalah siswa SMP Negeri 5 Metro pada kelas VIII semester genap tahun ajaran 2015/2016 sebanyak 2 orang siswa tunagrahita ringan. Teknik pemilihan subjek menggunakan teknik purposive sampling. Intrumen utama dalam penelitian ini adalah peneliti sendiri. Intrumen bantu dalam penelitian ini adalah soal matematika non rutin dalam bentuk essay.

Teknik pengumpulan data menggunakan teknik wawancara dan tes. Kedua sebjek diberikan soal tes yang berisi masalah matematika dengan dilakukan wawancara mendalam. Pada penelitian ini digunakan triangulasi waktu, yaitu pengumpulan data dilakukan sebanyak dua kali dengan waktu yang berbeda. Teknik analisis data yang digunakan adalah prosedur Miles dan Huberman (Sugiyono, 2014) yang terdiri dari reduksi data, penyajian data dan penarikan kesimpulan. 


\section{HASIL PENELITIAN DAN PEMBAHASAN}

Pengambilan data diawali dengan memilih siswa tunagrahita ringan yang akan dijadikan subjek penelitian. Berdasarkan teknik purposive sampling maka diperoleh dua subjek untuk selanjutnya dilakukan analisis mendalam mengenai proses berpikir pada saat menyelesaikan masalah matematika.

Untuk memudahkan dalam menganalisis data tersebut, maka digunakan inisial yaitu: (1) inisial "P" sebagai peneliti; (2) inisial "BG" sebagai subjek pertama; dan (3) inisial "RN" sebagai subjek kedua.

\section{1) Siswa BG}

\section{Pembentukan Pengertian}

Proses berpikir siswa BG dalam pembentukan pengertian yaitu siswa memerlukan waktu untuk dapat memahami masalah pada soal, ketika diberikan soal, siswa tidak langsung menuliskan apa yang diketahui dan yang ditanyakan di dalam soal, meskipun setelah membaca dan memahami soal siswa dapat mengemukakan apa yang diketahui dan yang ditanyakan melalui sedikit arahan. Berikut sedikit cuplikan wawancara dengan BG.

Soal tes kedua: "Ibu ke pasar membeli roti dan susu cokelat. Harga 2 buah roti dan 3 buah susu cokelat adalah $R p 8.500$. Adik membeli 5 roti dan 6 susu cokelat seharga $R p \quad 19.000$. Berapakah harga 1 roti dan 1 susu cokelat?"

P : Dimisalin apa rotinya?

BG : $x$

$\mathrm{P} \quad$ : Iya, susunya dimisalin apa, susu coklatnya?

BG : $3 y$

$\mathrm{P}$ : 3y? Iya. Bayarnya berapa?

BG : Delapan ribu lima ratus

$\mathrm{P}$ : Roti tadi apa?

BG : $x$

$\mathrm{P} \quad: \quad x$, iya. Berarti adik membeli 5 roti berarti apa?

BG : (Diam kemudian menulis) $\mathrm{P}$ : Berarti apa yang ditanya?

BG : Harga

$\mathrm{P}$ : Harga apa?

BG : Roti

$\mathrm{P} \quad$ : Roti, berarti apa? Tadi roti dimisalin apa?

BG : $x$

$\mathrm{P}$ : Berarti yang ditanya?

BG : $x$

$\mathrm{P}$ : $x$, sama?dan

BG : Harga susu

$\mathrm{P}$ : Berarti, dan

BG : $y$

Pada tahap pembentukan pengertian ini, siswa dapat menganalisis ciri-ciri dari suatu objek yang dalam hal ini objek yang ada di dalam masalah bentuk soal SPLDV, kemudian siswa dapat membandingkan ciri tersebut seperti roti yang dimisalkan $x$ dan susu cokelat dimisalkan $y$. Siswa dapat membentuk suatu pengertian di dalam dirinya terhadap masalah 
matematika yang dihadapi. Selanjutnya dalam mengabstraksikan, siswa sangat butuh arahan yaitu pada saat membentuk model matematika yang sesuai. Namun demikian siswa BG pada dasarnya dapat memahami apa yang menjadi permasalahan di dalam soal yang dihadapi meskipun masih memerlukan waktu dan arahan.

\section{Pembentukan Pendapat}

Pada proses kedua yaitu tahap pembentukan pendapat, yang dilihat dari bagaimana cara siswa menyampaikan pendapatnya berkaitan dengan strategi atau cara apa yang digunakan dalam menyelesaikan masalah, dalam hal ini berkaitan dengan SPLDV. Siswa BG sebenarnya cukup mengerti bahwa cara yang dapat digunakan adalah menggunakan metode eliminasi dan subtitusi, tetapi BG tidak dapat menggunakan metode tersebut secara maksimal. Berikut sedikit cuplikan wawancara dengan BG.

$\mathrm{P}$ : Nah gimana? Biar dapat $x$ dan y, Pake cara apa?

BG : (Melihat catatan)

$\mathrm{P}$ : Yang seperti ini cara apa namanya? (menunjuk di catatan siswa)

BG : Eliminasi

$\mathrm{P}$ : Oke, ini berarti dikali berapa ini yang atas?

BG : dikali 5

P : Kenapa dikali 5? Biar jadi berapa?

BG : (Diam dan melihat

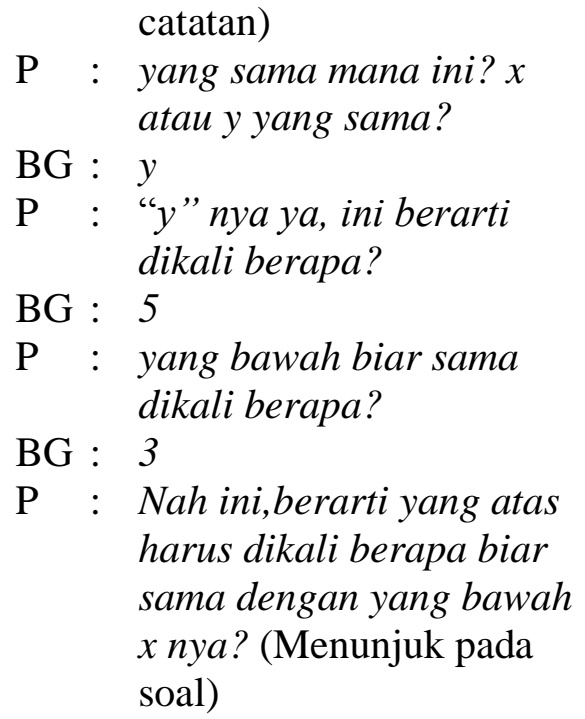
harus dikali berapa biar sama dengan yang bawah $x$ nya? (Menunjuk pada soal)

BG : (Terlihat masih bingung)

$\mathrm{P}$ : Nah ini kan ditukar ya? Dikali 3 dan dikali 5 (menjelaskan catatan siswa)

BG : (Diam sambil melihat penjelasan)

P : Berarti ini dikali berapa biar sama dengan yang bawah?

BG : 2

$\mathrm{P}$ : yang bawah dikali 2, yang atas dikali berapa?

BG : 5

Pada tahap pembentukan pendapat ini, meskipun siswa BG terlihat belum terlalu bisa dalam mengeluarkan pendapatnya, jika dikaitkan dengan jenis-jenis pendapat menurut Suryabrata (2014), maka siswa BG lebih cenderung masih menggunakan pendapat modalitas atau kebarangkalian, BG terlihat tidak terlalu yakin dan masih mencobacoba apakah cara tersebut benar atau tidak. Dalam proses 
penyelesaian masalahnya, siswa BG tidak dapat menggunakan metode eliminasi untuk memperoleh jawaban akhir dari permasalahan pada soal. BG masih sangat perlu arahan di dalam menggunakan strategi yang sesuai dengan permasalahan.

\section{Penarikan Kesimpulan}

Untuk tahap terakhir yaitu tahap penarikan kesimpulan, tahap ini tentu saja sangat berkaitan erat dengan tahapan sebelumnya terutama pada tahap pembentukan pendapat. Telah diketahui bahwa pada tahap pembentukan pendapat, BG tidak dapat melakukannya dengan baik, hal ini mengakibatkan BG tidak dapat menarik kesimpulan atau memberikan jawaban akhir dari permasalahan yang ada pada soal. Berkaitan dengan soal SPLDV yang diberikan, BG tidak dapat menyimpulkan harga untuk masing-masing barang.

\section{2) Siswa RN}

\section{Pembentukan Pengertian}

Proses berpikir siswa RN dalam pembentukan pengertian yaitu siswa membaca dan mengamati soal kemudian langsung menuliskan penyelesaian pada lembar jawaban. Siswa RN pada tulisannya tidak menuliskan secara keseluruhan apa yang diketahui dan ditanya dalam soal, namun ketika diwawancara, siswa dapat menyebutkan apa yang diketahui dan ditanyakan dalam soal. Berikut sedikit cuplikan wawancara dengan RN.

Soal tes pertama: "Ibu pergi ke pasar membeli 4 buah buku tulis dan 2 buah pena dengan membayar uang sebesar $R p$ 15.000,-. Selanjutnya adik membeli 6 buah buku tulis dan 4 buah pena dengan membayar uang sebesar $R p$ 24.000,-. Berapakah harga 1 buah buku tulis dan 1 buah pena?

$\mathrm{P} \quad$ : Jawaban nomor 1 yang ini ya?

$\mathrm{RN}:$ Iya

$\mathrm{P} \quad$ : Jadi model matematikanya yang mana rin?

RN : (Diam sambil melihat jawaban yang ditulis)

$\mathrm{P} \quad$ : Yang ini apa? Modelnya bukan ini, $x-2 y=9$ ?

$\mathrm{RN}:$ (Terdiam)

$\mathrm{P}$ : Coba disini yang diketahui apa?

$\mathrm{RN}$ : (Melihat soal)

$\mathrm{P}$ : Yang diketahui apa?

RN : 4 buku, 2 pena harganya 15.000

$\mathrm{P} \quad$ : Ini yang diketahui yang ditulis di nomor 2 ya rin? (Menunjuk jawaban no. 2)

Siswa RN dapat menganalisis ciri-ciri dari objek yang ada pada soal yang diberikan, selanjutnya siswa juga dapat membandingkan ciri yaitu dengan membuat permisalan $x$ dan $y$. Namun dalam 
mengabstraksikan, siswa sangat butuh arahan yaitu pada saat membentuk model matematika yang sesuai, karena model maatematika yang dibuat $\mathrm{RN}$ belum begitu sesuai. Pada dasarnya siswa RN dapat membentuk suatu pengertian di dalam dirinya terhadap masalah matematika yang dihadapi. RN dapat memahami apa yang menjadi permasalahan meskipun masih memerlukan arahan.

\section{Pembentukan Pendapat}

Pada proses kedua yaitu tahap pembentukan pendapat, berkaitan dengan SPLDV. Siswa $\mathrm{RN}$ dapat menuliskan jawaban tetapi terkesan mengikuti apa yang ada dalam buku catatannya, siswa tidak begitu memahami apa yang ditulisnya. Siswa RN juga tidak dapat menjelaskan secara lisan strategi apa yang sesuai untuk menyelesaikan permasalahan dalam soal. Berikut cuplikan wawancara dengan RN.

$\mathrm{P}$ : Ini jawabannya ya?

$\mathrm{RN}:$ Iya

$\mathrm{P}$ : Yang dipake cara apa ini?

RN : (Diam dan melihat jawaban yang ditulis)

$\mathrm{P} \quad$ : Pake subtitusi ya, ini ada tulisan subtitusi

$\mathrm{RN}:$ Iya

$\mathrm{P} \quad$ : Kalo yang dikali kali ini cara apa?

RN : (Melihat jawaban dan catatannya)

P : Nah ini (menunjuk catatan siswa), cara apa ini namanya?
RN : (Diam sambil melihat catatannya)

$\mathrm{P}$ : Cara apa itu ya? Ini yang kaya gini, yang atas dikali, yang bawah juga.

RN : Eliminasi

$\mathrm{P} \quad$ : Iya, cara eliminasi ya?

Terus ini $2 x+3 y=8$ darimana ini?

RN : (Diam, memperhatikan jawaban yang ditulisnya)

$\mathrm{P} \quad$ : Ini 2 buku gitu bukan ya, \ terus yang y ini 3 pena, gitu?

RN : Gatau

Berdasarkan hasil wawancara terhadap siswa $\mathrm{RN}$, diketahui bahwa RN belum begitu paham dengan metode apa yang digunakan untuk menyelesaikan masalah. Selain RN juga belum begitu yakin dengan jawabannya sehingga $\mathrm{RN}$ cenderung memberikan pendapat modalitas atau kebarangkalian.

\section{Penarikan Kesimpulan}

Untuk tahap terakhir yaitu, tahap penarikan kesimpulan, tahap yang berkaitan erat dengan tahap pembentukan pendapat. Karena RN memberikan pendapat yang sesuai dalam penyelesaian masalah, maka RN tidak memperoleh jawaban akhir atau kesimpulan dari masalah yang dihadapi. Sebenarnya pada lembar jawaban RN terdapat tulisannya. Hal ini menunjukkan bahwa tidak ada bagian pada soal yang tidak terjawab oleh $\mathrm{RN}$, namun demikian jawaban yang diberikan $\mathrm{RN}$ tidak jelas arahnya. 
$\mathrm{RN}$ terkesan menulis ulang soal atau menulis ulang jawaban sebelumnya. Siswa RN juga terkesan menulis apa yang ada di catatannya tetapi $\mathrm{RN}$ tidak memahami apa yang dituliskannya itu.

Siswa RN tidak dapat menyimpulkan jawaban akhir dari soal baik pada tes pertama maupun pada tes kedua. Bahkan pada tes pertama, ketika ditanya berapa harga buku, RN justru terkesan menjawab dengan harga buku yang pernah dia beli, bukan harga buku berdasarkan hal yang diketahui dari soal.

\section{Pembahasan}

Berdasarkan analisis yang telah diuraikan, diperoleh beberapa kesamaan proses berpikir dari kedua subjek tunagrahita ringan dalam menyelesaikan masalah matematika materi SPLDV. Kedua subjek dapat mengungkapkan apa yang diketahui dan ditanyakan dalam soal, artinya bahwa kedua subjek dapat membentuk pengertian di dalam proses berpikirnya. Pada saat diberikan suatu permasalahan dalam bentuk soal, siswa tunagrahita ringan pada dasarnya dapat menganalisis ciriciri dari permasalahan yang dihadapi. Siswa tunagrahita ringan dapat mengerti masalah apa yang terdapat di dalam soal tersebut. Selanjutnya pada proses pembentukan pendapat, siswa tunagrahita ringan belum bisa menentukan sendiri strategi atau cara apa yang sesuai untuk digunakan dalam menyelesaikan masalah yang diberikan. Dalam menentukan strategi untuk menyelesaikan masalah, siswa tunagrahita ringan masih membutuhkan arahan hingga benar-benar dapat menentukan bahwa strategi yang dapat digunakan dalam hal ini adalah metode eliminasi dan subtitusi pada materi SPLDV. Setelah mengetahui bahwa cara yang dapat digunakan adalah metode eliminasi dan subtitusi, siswa tunagrahita ringan tidak dapat mengembangkannya untuk memperoleh jawaban yang sesuai. Meskipun siswa memiliki catatan yang diperoleh dari pembelajaran di kelas, siswa tunagrahita tidak mengerti apa yang ditulisnya, dan masih belum bisa memahami penggunaan metode eliminasi subtitusi.

Pada tahap penarikan kesimpulan, kedua subjek tidak dapat memberikan kesimpulan atau jawaban untuk permasalahan yang dihadapi. Hal ini juga merupakan dampak dari tahap proses berpikir sebelumnya yaitu pada tahap pembentukan pendapat dimana kedua subjek tidak dapat menggunakan strategi yang sesuai secara baik dan terarah.

Beberapa perbedaan antara subjek laki-laki (BG) dengan subjek perempuan $(\mathrm{RN})$, yaitu 
subjek RN lebih mudah dalam menyampaikan gagasannya dalam bentuk tulisan meskipun tidak terarah, dibandingkan dengan subjek BG yang terlihat sangat sulit menuliskan sesuatu pada lembar jawaban yang disediakan karena keraguannya cukup tinggi. Namun secara keseluruhan, dari kedua subjek tunagrahita ringan ini, dalam mengembangkan proses berpikirnya masih sangat memerlukan bantuan dan arahan, hal ini disebabkan oleh kecerdasan intelektual yang dimiliki siswa. Hal tersebut sejalan dengan penelitian Hakim (2015) yang melakukan kajian lebih terhadap kemampuan motorik kasar, bahwa anak tunagrahita membutuhkan bimbingan dan latihan yang dilakukan secara berkala.

Menurut Utami, Sujadi, dan Riyadi (2014), karena kecerdasan intelektual yang dimiliki oleh siswa tunagrahita, guru hendaknya melakukan penjelasan berulang-ulang hingga siswa memahami apa yang disampaikan oleh guru. Guru hendaknya tidak membelajarkan matematika hanya sampai pada tahap enaktif saja, tetapi dapat mencoba membelajarkan matematika pada tahap ikonik, agar siswa sedikit demi sedikit belajar untuk berpikir semi konkrit.

Pembelajaran matematika yang diberikan kepada siswa tunagrahita ringan sebaiknya perlu menggunakan benda-benda konkret atau benda nyata sehingga memudahkan siswa dalam mengabstraksikan konsep matematika. Siswa tunagrahita terkesan lebih mudah dalam mengingat sesuatu yang berbentuk konkret. Hal ini ditunjukkan pula oleh siswa RN pada saat memberikan kesimpulan akhir tes pertama yaitu dalam menyebutkan harga buku sesuai dengan soal, siswa justru menyebutkan harga pulpen yang pernah dibelinya. Artinya siswa lebih mudah mengingat sesuatu yang nyata berdasarkan pengalaman yang pernah dialaminya. Pemanfaatan bendabenda konkret untuk lebih memudahkan siswa dalam memahami suatu materi memang diperlukan. Pada penelitian Hartini (2014), menyimpulkan bahwa penggunaan benda konkret yang dalam penelitiannya berupa kartu bilangan dapat meningkatkan kemampuan penjumlahan siswa tunagrahita.

Siswa perlu diberikan pembelajaran menggunakan halhal yang kongkrit, tidak sekedar konsep abstrak. Karena kemampuan berpikir siswa ABK yang memang berbeda dengan siswa normal lainnya. Namun tidak juga harus dipisahkan atau dikhususkan dari siswa normal lainnya, karena siswa ABK tersebut akan merasa dikucilkan dan hal tersebut sangat tidak baik karena dapat mempengaruhi 
kondisi mentalnya. Untuk itu adanya kelas inklusi juga sangat membantu dalam perkembangan siswa ABK karena sistem pembelajarannya yang menyamaratakan dengan anak normal lainnya.

\section{KESIMPULAN DAN SARAN}

Berdasarkan hasil penelitian dan pembahasan yang telah dijelaskan, maka proses berpikir siswa tunagrahita jika dilihat dari tahap pembentukan pengertian, pembentukan pendapat dan penarikan kesimpulan adalah sebagi berikut.

1. Pada tahap pembentukan pengertian, siswa tunagrahita dapat membentuk pengertian di dalam proses berpikirnya. Pada saat diberikan suatu permasalahan dalam bentuk soal, siswa tunagrahita ringan pada dasarnya dapat menganalisis ciri-ciri dari permasalahan yang dihadapi. Siswa tunagrahita ringan dapat mengerti masalah apa yang terdapat di dalam soal tersebut.

2. Pada tahap pembentukan pendapat, siswa tunagrahita membutuhkan arahan untuk dapat menentukan strategi atau cara apa yang digunakan dalam menyelesaikan masalah yang diberikan. Selain itu, siswa juga tidak mampu mengembangkan strategi tersebut untuk menyelesaikan masalah.

3. Pada tahap penarikan kesimpulan, siswa tunagrahita ringan tidak dapat menyimpulkan hasil akhir yang tepat untuk menjawab suatu permasalahan.

Berdasarkan kesimpulan yang telah diperoleh, maka saran dalam penelitian ini sebagai berikut.

1. Dalam pembelajaran matematika, guru sebaiknya menggunakan benda konkret atau alat peraga untuk membantu siswa tunagrahita dalam memahami materi yang diberikan.

2. Dalam pembelajaran khususnya matematika, siswa tunagrahita ringan sebaiknya diberikan penjelasan yang lebih khusus pada saat menggunakan suatu strategi atau cara dalam menyelesaikan masalah matematika, karena kesulitan yang paling dominan adalah pada proses berpikir tahap pembentukan pendapat.

\section{DAFTAR PUSTAKA}

Abdullah, N. 2013. "Mengenal Anak Berkebutuhan Khusus". Magistra. No 86 Th. XXV.

Arends, R. 2008. Learning to Teach. New York: McGraw Hill Companies.

Breen, S., dan O'Shea, A. 2010. "Mathematical Thinking and Task Design". Social Bulletin. Hal 39-49.

Geniofam. 2010. Mengasuh dan 
Mensukseskan Anak
Berkebutuhan Khusus.
Yogyakarta: Garailmu.

Hakim. 2015. "Pengaruh Usia dan Latihan Keseimbangan terhadap Kemampuan Motorik Kasar Anak Tunagrahita Kelas Bawah Mampu Didik Sekolah Luar Biasa". Journal of Physical Education and Sport. Vol. 2, No.1, Hal 200-204.

Hartini, T. 2014. "Peningkatan Kemampuan Operasi Penjumlahan melalui Media Kartu Bilangan pada Anak Tunagrahita Kelas 1C SLB B, C-Autis Sendang Mulyo Pedurungan". Empati. Vol. 1, No. 1, Hal 53-72.

Marchis, I. 2012. "Non-Routine Problems in Primary Mathematics Workbooks from Romania". Acta Didactica Napocensia. Vol 5 No 3 Hal 49-56.

Sugiyono. 2014. Metode Penelitian Pendidikan Pendekatan Kuantitatif, Kualitatif, dan $R \& D$. Bandung: Alfabeta.

Suryabrata. 2014. Psikologi Pendidikan. Jakarta: Rajawali Pers.

Utami, A.D., Sujadi, I., dan Riyadi. 2014. "Strategi Guru dalam Membelajarkan Matematika pada Materi Lingkaran kepada Anak Tunagrahita (Studi Kasus pada Siswa Kelas VIII SLB Muhammadiyah Cepu)". Jurnal Elektronik Pembelajaran Matematika. Vol. 2, No. 8, hal 853-864. 